\title{
KONVERSI SELULOSA TANDAN KOSONG SAWIT (TKS) MENJADI ETANOL
}

\author{
Rakhman Sarwono a 1, Eka Triwahyuni a, Yosi Aristiawan a , Hendris Hendarsyah Kurniawan a, \\ Trisanti Anindyawati ${ }^{\text {b }}$ \\ ${ }^{a}$ Pusat Penelitian Kimia-LIPI, Kawasan PUSPIPTEK, Serpong-Tangerang Selatan 15314 \\ ${ }^{\mathrm{b}}$ Pusat Penelitian Bioteknologi-LIPI, Jl. Raya Bogor Km 46, Cibinong, Bogor 16911 \\ ${ }^{1}$ rakh_sarwono@yahoo.com
}

Diterima : 10 Maret 2014, Revisi akhir : 5 Mei 2014, Disetujui terbit : 30 Mei 2014

\section{CELLULOSE CONVERSION OF OIL PALM EMPTY FRUIT BUNCH (EFB) INTO ETHANOL}

\begin{abstract}
A serious global energy crisis is thought to be originated from the imbalance rapid consumption and the non-renewable nature of the fossil fuels. A potential, yet promising route for diminising this problem might involve rapid conversion of organic waste and biomass into fuels as an alternative. Oil-palm empty fruit bunch (EFB) is the waste from the oil palm plantation which abundant amount of lignocellulosic EFB biomass. EFB biomass was used as raw material of the second generation of bioethanol production. EFB was converted into ethanol through enzymatic hydrolysis and fermentation simultaneously. Cellulose waste was then turned into glucose by enzymatic saccharification and finally fermented into ethanol. The experiment of 20 liter broth resulted in ethanol concentration of about $7.93 \%(w / w)$. Conversion of cellulose into glucose was about $60.02 \%$, and conversion of glucose into ethanol was about $88.44 \%$. Following distillation, ethanol of $1970 \mathrm{~mL}$ was obtained at a concentration of $63 \%(v / v)$.
\end{abstract}

Keywords: EFB, saccharification, fermentation, glucose, ethanol

\begin{abstract}
ABSTRAK
Adanya krisis energi minyak bumi secara global disebabkan oleh ketimpangan antara konsumsi dan produksi minyak bumi. Guna mengimbangi ketimpangan tersebut, maka dilakukan konversi limbah organik dan biomassa menjadi bahan bakar secara tepat dan cepat. Tandan Kosong Sawit (TKS) merupakan limbah dari perkebunan sawit yang melimpah jumlahnya. Penelitian etanol generasi kedua berbahan baku biomassa lignoselulosa dilakukan melalui proses sakarifikasi selulosa menjadi glukosa secara enzimatis dan fermentasi glukosa menjadi etanol. Berdasarkan hasil yang diperoleh dari 20 liter hidrolisat didapat konsentrasi etanol sebesar 7,93\% (b/b). Hasil konversi selulosa menjadi glukosa sebesar $60,02 \%$, sedangkan konversi glukosa menjadi etanol sebesar $88,44 \%$. Setelah dilakukan distilasi didapatkan etanol sebanyak $1970 \mathrm{~mL}$ dengan konsentrasi 63\% (v/v).
\end{abstract}

Kata kunci: TKS, sakarifikasi, fermentasi, glukosa, etanol

\section{PENDAHULUAN}

Selulosa merupakan komponen paling banyak yang terdapat pada tumbuhan. Selulosa bisa terdapat pada batang, akar, daun, dan buah. Salah satu biomassa lignoselulosa yang melimpah di Indonesia adalah limbah dari perkebunan sawit. Produksi minyak sawit (CPO) Indonesia meningkat setiap tahunnya. Menurut data dari Direktorat Jenderal Perkebunan produksi tahun 2010 sebesar 21,958 juta ton meningkat pada tahun 2012 sebesar 23,52 juta ton (angka sementara) dan estimasi pada tahun 2013 sebesar 24,43 juta ton. Tandan Kosong Sawit (TKS) merupakan limbah dari buah sawit setelah buahnya dirontohkan. Setiap satu ton Tandan Buah Segar (TBS) yang 
diproses di pabrik pengolahan minyak sawit, akan dihasilkan biomassa lignoselulosa dalam bentuk batang pohon sebanyak 7 ton, pelepah 26 ton dan TKS 0,23 ton (Yunus dkk., 2010). Berat kering TKS adalah sekitar 8\% dari berat tandan buah segar (TBS), sedangkan satu batang pohon sawit akan menghasilkan satu pelepah baru setiap tiga minggu sekali (Sheil dkk., 2009). Pelepah yang dihasilkan dari setiap hektar kebun sawit adalah sekitar 10,88 ton (Hanim dkk., 2010).

Biomassa berbasis lignoselulosa terdiri dari tiga polimer yaitu selulosa, hemiselulosa dan lignin (Perez dkk., 2002) merupakan substrat yang cukup kompleks karena kandungan di dalamnya antara lain polisakarida, zat ekstraktif dan senyawa organik lainnya (Costello dan Chum, 1998). Polisakarida merupakan bagian terpenting dan terbanyak khususnya selulosa yang terbungkus lignin dengan ikatan yang cukup kuat. Dalam kaitan konversi TKS menjadi etanol, polisakarida dapat disakarifikasi atau dihidrolisis menjadi monosakarida (glukosa, xilosa) sebelum diproses lebih lanjut menjadi etanol.

Teknologi proses produksi etanol dalam proses sakarifikasi biasanya dilakukan dengan metode konvensional yaitu dengan menggunakan asam sulfat atau asam klorida. Akan tetapi metode tersebut dianggap kurang ramah lingkungan karena penggunaan asam dapat menimbulkan korosif di samping biaya bahan kimia asam tersebut relatif mahal. Pengembangan teknologi bioproses dengan menggunakan enzim pada proses sakarifikasi diyakini sebagai suatu proses yang lebih ramah lingkungan (Pandey dkk., 2000).

Sakarifikasi enzimatis adalah proses sakarifikasi yang dilakukan dengan menggunakan enzim, seperti enzim jenis selulase atau jenis hemiselulase tergantung substrat yang menjadi prioritas. Enzim jenis selulase digunakan untuk hidrolisis substrat selulosa, sedangkan enzim jenis hemiselulase untuk substrat hemiselulosa. Konsorsium enzim seperti endoglukanase, exoglukanase dan $\beta$-glukosidase juga diperlukan untuk memecah selulosa menjadi monomer gula (Lynd dkk., 2002). Pada TKS kandungan selulosa sebesar $54,4 \%$ berat kering dan pelepah sawit sebesar $62,3 \%$ berat kering (Goh dkk., 2010). Selulosa merupakan kandungan terbanyak dalam limbah sawit tersebut. Perlakuan awal pada TKS perlu dilakukan untuk memudahkan proses sakarifikasi baik perlakuan awal secara fisik maupun kimia. Secara teori proses hidrolisis lignoselulosa menjadi glukosa $<20 \%$ bila tanpa perlakuan awal, sedangkan bila dilakukan perlakuan awal bisa terkonversi $>90 \%$ (Ghosh dan Ghose, 2003).

Ada beberapa metode proses sakarifikasi dan fermentasi diantaranya adalah separated hydrolysis fermentation (SHF), direct microbial conversion (DMC) dan simultaneous saccharafication fermentation (SSF). SSF memberi laju reaksi, hasil dan konsentrasi etanol yang lebih tinggi (Wyman dkk., 1992). Pada penelitian ini dilakukan konversi selulosa pada TKS menjadi etanol sebagai energi alternatif dengan metode SHF pada skala 20 L. Optimasi proses sakarifikasi dan fermentasi dengan metode SHF untuk skala laboratorium telah dilakukan dengan hasil etanol $6,87 \% \mathrm{~b} / \mathrm{b}$ pada substrat $20 \%$ TKS (Anindyawati dkk., 2012), sehingga pada penelitian ini dilakukan perbesaran skala produksi etanol $20 \mathrm{~L}$ dengan tujuan untuk mengetahui kondisi optimal proses skala laboratorium yang dapat teraplikasi di proses yang lebih besar.

\section{BAHAN DAN METODE}

\section{Bahan dan Peralatan}

Tandan Kosong Sawit diperoleh dari PT Perkebunan Nusantara VIII, Pandeglang, Banten Indonesia. Enzim yang digunakan adalah Ctec2 dan Htec2 dari Novozymes, sedangkan ragi Saccharomyces cereviceae yang digunakan adalah ragi padat komersial. Peralatan yang digunakan untuk sakarifikasi dan fermentasi adalah fermentor dengan kapasitas maksimum 69 L yang dilengkapi dengan pengatur suhu, laju pengadukan dan alat distilasi (Gambar 1).

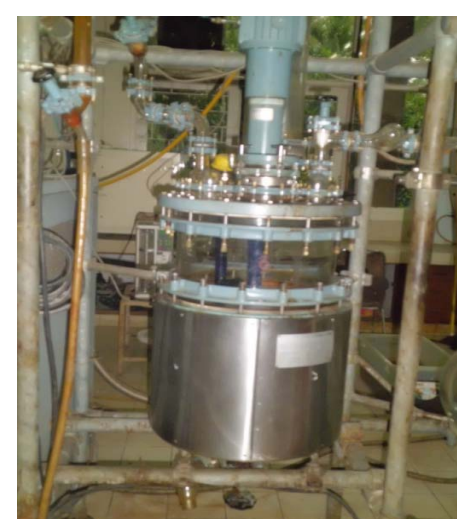

Gambar 1. Fermentor untuk Proses Sakarifikasi dan Fermentasi yang Dilengkapi dengan Sistem Distilasi 


\section{Perlakuan Awal TKS}

Perlakuan awal meliputi perlakuan fisik menjadi serat, yaitu dengan cara mencacah potongan TKS sampai berukuran kurang lebih 3 $\mathrm{mm}$. Selanjutnya dilakukan perlakuan kimia yaitu dengan menambahkan larutan $\mathrm{NaOH} 10 \%$ dan dipanaskan pada suhu $150^{\circ} \mathrm{C}$ pada tekanan $4-8$ $\mathrm{kg} / \mathrm{cm}^{2}$ selama 30 menit. Kemudian dilakukan pencucian sampai $\mathrm{pH}$ netral dan dikeringkan menggunakan oven pada suhu $50^{\circ} \mathrm{C}$ sampai kadar air di bawah $10 \%$.

\section{Proses Sakarifikasi dan Fermentasi}

Proses sakarifikasi dan fermentasi dilakukan pada satu bejana fermentor dengan volume proses 20 L. Pulp TKS yang digunakan adalah $20 \%$ b/v dari volume proses. Sebanyak 14,69 L buffer sitrat $20 \mathrm{mM} \mathrm{pH} \mathrm{4,8} \mathrm{dimasukkan} \mathrm{ke} \mathrm{dalam} \mathrm{fermentor}$ dan diikuti dengan penambahan $4290 \mathrm{~g}$ pulp TKS dengan kadar air 6,7\% (b/v), kemudian campuran disterilisasi selama 15 menit. Setelah suhu diturunkan, selanjutnya dimasukkan enzim Ctec2 (30 FPU/g TKS) dan Htec2 dengan perbandingan 5:1. Kondisi proses sakarifikasi yaitu pada $\mathrm{pH}$ 4,8 ; suhu $32^{\circ} \mathrm{C}$ dan pengadukan $200-300 \mathrm{rpm}$ selama 48 jam. Setelah proses sakarifikasi selesai, dimasukkan ragi padat Saccharomyces cereviceae sebanyak $1 \%(\mathrm{~b} / \mathrm{v})$. Kondisi proses fermentasi yaitu pada suhu $32^{\circ} \mathrm{C}$, pengadukan $200 \mathrm{rpm}$ selama 72 jam. Pengambilan contoh dan analisis dilakukan setiap 24 jam.

\section{Analisis Produk}

1. Analisis Komponen TKS Sebelum dan Sesudah Perlakuan Awal

Analisis komponen pada substrat TKS dilakukan dengan menggunakan prosedur analitis standar untuk biomassa yang disediakan oleh National Renewable Energy Laboratory (NREL), 2010. Sebanyak 0,3 g sampel TKS dimasukkan ke dalam tabung reaksi dan ditambahkan $3 \mathrm{~mL} \mathrm{H}_{2} \mathrm{SO}_{4} 72 \%$. Kemudian dihidrolisis pada suhu $30^{\circ} \mathrm{C}$ selama 2 jam menggunakan inkubator (hidrolisis pertama). Hasil hidrolisis ditambahkan ke dalam 84 $\mathrm{mL}$ aquadest dalam botol Duran $100 \mathrm{~mL}$ dan dilakukan hidrolisis kedua pada suhu $121^{\circ} \mathrm{C}$ selama 1 jam menggunakan autoclave. Setelah didinginkan sampai suhu ruang, dilakukan penyaringan sisa padatan dengan filtrasi vakum. Kurang lebih $20 \mathrm{~mL}$ filtratnya diambil untuk analisis selanjutnya. Lignin tidak terlarut dalam residu ditentukan setelah pengabuan sisa padatan dalam furnace selama 24 jam. Lignin terlarut dan komponen struktur utama (glukosa dan xilosa) dianalisis dari filtratnya. Analisis lignin terlarut dilakukan dengan menambahkan $3 \mathrm{~mL} \mathrm{H}_{2} \mathrm{SO}_{4} 4 \%$ ke dalam $0,15 \mathrm{~mL}$ filtrat, kemudian diukur absorbansinya menggunakan UV spektrofotometer pada panjang gelombang $205 \mathrm{~nm}$. Analisis komponen struktur utama dilakukan dengan menambahkan $\mathrm{CaCO}_{3}$ ke dalam $4 \mathrm{~mL}$ filtrat sampai $\mathrm{pH}$ netral, kemudian disaring dan dianalisis menggunakan HPLC. Perhitungan komponen lignin, selulosa dan hemiselulosa adalah sebagai berikut :

Komponen lignin

$=$ lignin terlarut + lignin tidak terlarut.

$=($ berat padatan $/$ berat sampel biomassa $) \times 100$

+ (faktor pengenceran x absorbansi x 87/100) x 100

Komponen selulosa

$=($ konsentrasi glukosa pada HPLC $(\mathrm{g} / \mathrm{mL})$ x 87 $\mathrm{mL} / 100) /$ berat biomassa $(\mathrm{g}) \times 100 \times 0,9$

Komponen hemiselulosa

$=($ konsentrasi xilosa pada HPLC $(\mathrm{g} / \mathrm{mL}) \times 87$ $\mathrm{mL} / 100) /$ berat biomassa $(\mathrm{g}) \times 100 \times 0,88$

\section{Analisis Glukosa, Xilosa dan Etanol}

Produk hasil sakarifikasi berupa glukosa dan xilosa serta etanol hasil dari fermentasi dianalisis menggunakan HPLC Waters dengan kolom Aminex 87H dan detektor RI. Kecepatan laju alir sampel ke HPLC $0,6 \mathrm{~mL} /$ menit dengan menggunakan eluen $200 \mathrm{mM} \mathrm{H}_{2} \mathrm{SO}_{4}$.

Perhitungan konversi glukosa dan etanol:

Konversi selulosa menjadi glukosa

$=$ (glukosa yang dihasilkan/selulosa pada bahan baku) x $100 \%$

Konversi glukosa menjadi etanol $=$ (etanol yang dihasilkan/ glukosa awal pada proses fermentasi) x $100 \%$

Konversi selulosa menjadi etanol $=$ (etanol yang dihasilkan/selulosa pada bahan baku) x $100 \%$ 


\section{HASIL DAN PEMBAHASAN}

Proses perlakuan awal terhadap limbah biomassa TKS bertujuan untuk menurunkan kandungan lignin. Proses tersebut perlu dilakukan untuk mempermudah proses sakarifikasi, yaitu untuk membuka struktur lignoselulosa agar selulosa menjadi lebih mudah diakses oleh enzim yang memecah polimer polisakarida menjadi bentuk monomer, sehingga dapat mengurangi penggunaan enzim dan mengurangi biaya (Dashtban dkk., 2009). Adanya lignin juga akan mengikat enzim, sehingga menyebabkan kerja enzim tidak maksimal (Moilanen dkk., 2011) dan menutup jalannya penetrasi enzim ke struktur biomassa melalui ikatan lignin karbohidrat (Yu dkk., 2012). Menurut Sun dan Cheng (2004), proses perlakuan awal dapat mempercepat proses sakarifikasi dengan hasil yang lebih baik.

Hasil yang diperoleh dari proses perlakuan awal dalam penelitian ini menunjukkan adanya penurunan kandungan lignin pada substrat TKS dari $35,51 \%$ menjadi $9,47 \%$ atau penurunannya sebesar 73,33\%, sedangkan kadar selulosa dan hemiselulosa meningkat masing-masing sebesar
69\% dan 20,68\% (Tabel 1). Pulp TKS hasil perlakuan awal tersebut digunakan sebagai substrat pada proses sakarifikasi dan fermentasi. Proses sakarifikasi menggunakan enzim Ctec2 dan Htec2 dari Novozymes. Enzim Ctec2 merupakan selulase kasar untuk mendegradasi selulosa menjadi gula yang bisa difermentasi, berupa campuran dari selulase, $\beta$-glukosidase dan hemiselulase. Sedangkan enzim Htec2 merupakan endoxilanase dengan spesifikasi tinggi untuk mengubah hemiselulosa menjadi xilosa. Penggunaan enzim CTec2 dan HTec2 secara bersamaan dengan perbandingan tertentu dapat mengoptimalkan konversi selulosa dan hemiselulosa menjadi glukosa dan xilosa (www. novozymes.com). Pada penelitian ini penggunaan enzim Ctec2 dan Htec2 menggunakan perbandingan 5:1. Penggunaan enzim Ctec2 lebih banyak karena komponen tertinggi pada bahan baku adalah selulosa, sehingga diharapkan diperoleh konversi optimum selulosa menjadi glukosa.

Terlihat pada Gambar 2, bahwa pada proses sakarifikasi terjadi konversi selulosa menjadi glukosa dan hemiselulosa menjadi xilosa.

Tabel 1. Karakterisasi Komponen TKS dan Pulp TKS

\begin{tabular}{clcc}
\hline No. & Komponen & Persentase (\%) TKS -Tanpa Perlakuan & Persentase (\%) Pulp TKS \\
\hline 1. & Selulosa & 44,21 & 74,72 \\
2. & Hemiselulosa & 16,68 & 20,13 \\
3. & Lignin & 35,51 & 9,47 \\
4. & Abu & 0,26 & 0,61 \\
\hline
\end{tabular}

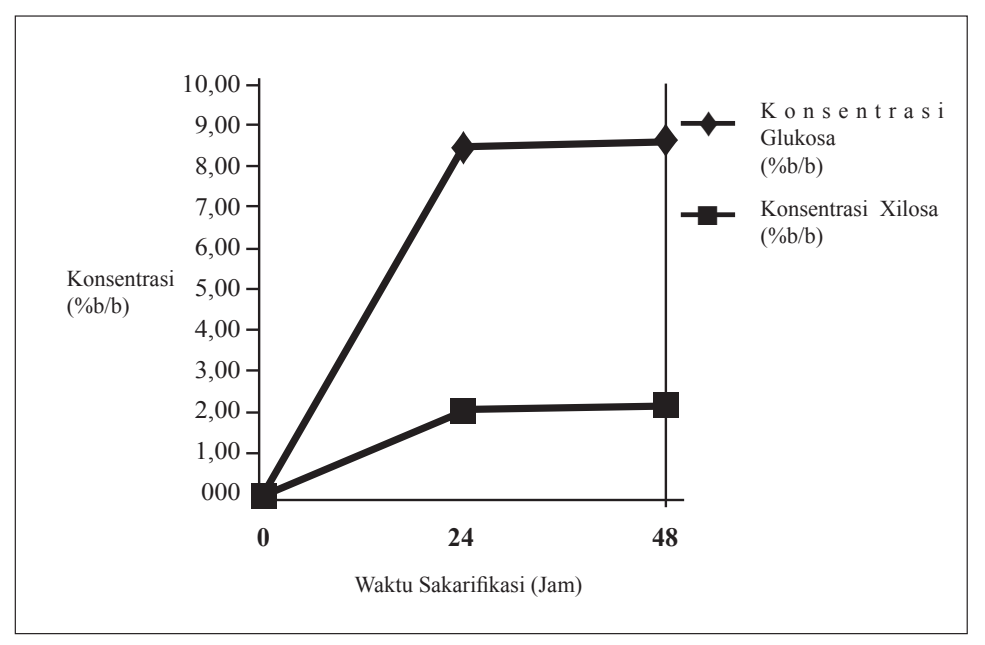

Gambar 2. Kurva Hasil Sakarifikasi Pulp TKS 


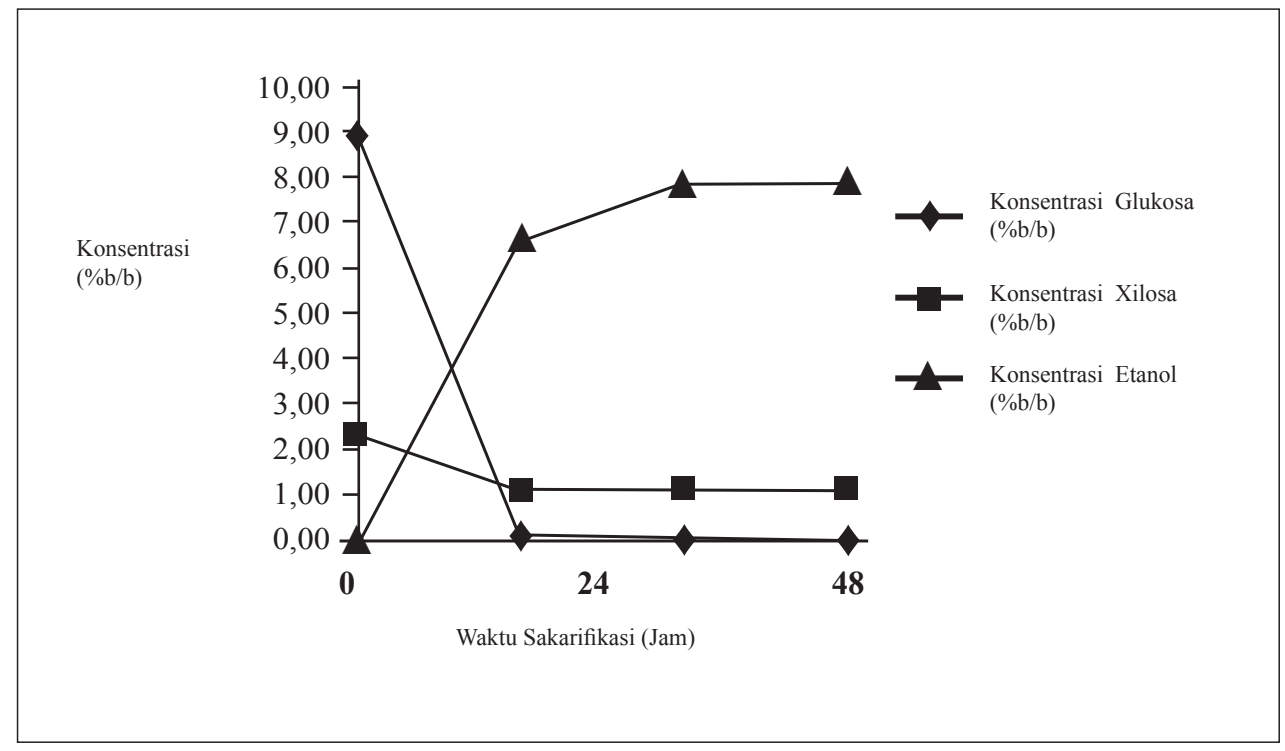

Gambar 3. Kurva Fermentasi Glukosa menjadi Etanol dengan Ragi S. cereviceae.

Hasil sakarifikasi tersebut menunjukkan bahwa konsentrasi glukosa lebih besar daripada xilosa, sehingga proses fermentasi menggunakan $S$. cereviceae dapat berlangsung dengan mengubah glukosa menjadi etanol.

Fermentasi untuk mengkonversi glukosa menjadi etanol, seperti terlihat pada Gambar 3. Ragi S. cereviceae mengkonversi glukosa menjadi etanol secara spesifik, hanya glukosa yang dikonversi menjadi etanol, sedangkan xilosa tidak terkonversi. Setelah 72 jam proses fermentasi, etanol yang dihasilkan sebanyak $7,93 \%$ dan setelah didistilasi diperoleh etanol $1970 \mathrm{~mL}$ dengan kadar 63\% (v/v), dengan efisiensi distilasi sebesar 78,26\%.

Terlihat pada Gambar 2 dan 3, konsentrasi glukosa sebesar $8,66 \%$ dan etanol $7,93 \%$, sehingga jumlah glukosa seluruhnya $=8,66$ $\%(\mathrm{~b} / \mathrm{b}) \times 20 \mathrm{~L}=1793,34 \mathrm{~g}$ (asumsi densitas 1 $\mathrm{g} / \mathrm{L}$ ). Sedangkan jumlah selulosa pada substrat awal sebesar $74,7 \%$ x $4000 \mathrm{~g}=2988 \mathrm{~g}$. Jadi konversi selulosa menjadi glukosa sebesar $60,02 \%$. Sedangkan etanol yang diperoleh dari $20 \mathrm{~L}$ volume proses adalah $=7,93 \%(\mathrm{~b} / \mathrm{b}) \times 20$ $\mathrm{L}=1586 \mathrm{~g}$ (asumsi densitas $1 \mathrm{~g} / \mathrm{L}$ ), sehingga konversi glukosa menjadi etanol sebesar $88,44 \%$ dan konversi selulosa menjadi etanol sebesar $53,08 \%$. Konversi selulosa menjadi glukosa sebesar $60,02 \%$ sudah cukup baik, mengingat beberapa peneliti melakukan konversi selulosa menjadi glukosa secara enzimatis diperoleh persentase yang sangat bervariasi. Beberapa hasil penelitian dengan bahan baku, jenis enzim, perlakuan awal dan kondisi operasi yang berbeda, menghasilkan glukosa paling tinggi sebesar $96 \%$ dan yang terendah adalah $36,3 \%$. Sedangkan hasil etanol paling besar $0,3(\mathrm{~g} / \mathrm{g})$ dari bahan baku selulosa dan paling rendah 0,1 $(\mathrm{g} / \mathrm{g})$ dari bahan baku kayu zaitun maupun bagase (Kumar dkk., 2009). Pada skala laboratorium yang telah dilakukan dengan menggunakan substrat TKS yang sama $20 \% \mathrm{~b} / \mathrm{v}$, diperoleh konsentrasi etanol $6,87 \% \mathrm{~b} / \mathrm{b}$ pada proses sakarifikasi suhu $32^{\circ} \mathrm{C}$ dan $7,86 \% \mathrm{~b} / \mathrm{b}$ pada proses sakarifikasi suhu $50^{\circ} \mathrm{C}$ (Anindyawati dkk, 2012). Hasil perbesaran skala $20 \mathrm{~L}$ pada penelitian ini diperoleh konsentrasi etanol 7,93\% pada proses sakarifikasi $32^{\circ} \mathrm{C}$, sehingga hasil optimasi skala laboratorium bisa teraplikasi dengan baik.

\section{KESIMPULAN}

Konversi TKS menjadi etanol dapat dilakukan pada skala proses 20 L. Enzim Ctec2 dan Htec2 mampu menghidrolisis pulp TKS menjadi glukosa dengan konsentrasi $8,66 \%$ dan ragi S. cereviceae mampu mengkonversi glukosa hasil hidrolisis pulp TKS menjadi etanol dengan konsentrasi 7,93\%. Hasil ini cukup baik, setelah dihitung dengan perbandingan selulosa awal, selulosa yang terkonversi menjadi glukosa sebesar 60,02 $\%$, dan glukosa yang terbentuk menjadi etanol sebesar 88,44\%. Konversi selulosa menjadi etanol sebesar $53,08 \%$. Setelah didistilasi vakum didapatkan etanol sebanyak $1970 \mathrm{~mL}$ dengan kadar 63\% (v/v). 


\section{DAFTAR PUSTAKA}

Anindyawati, T., Triwahyuni, E., Idiyanti, T. 2012. Optimasi Proses Sakarifikasi Tandan Kosong Kelapa Sawit (TKKS) Untuk Bahan Baku Bioetanol. Prosiding Seminar Nasional XXI Kimia dan Lingkungan, hal. 363-368

Costello. R., and Chum. H., 1998. Biomass Bioenergy and Carbon Management, In "Bioenergy '98: Expanding Bioenergy Partnerships" (D. Wichert. Ed.). Omnipress. Madison. WI., p.11- 17

Dashtban, M., Schraft, H., Qin, W., 2009. Fungal Bioconversion of Lignocellulosic Residue: Opportunities \& Perspectives. Int. J. Biol. Sci., 578-595

Ghosh, P., Ghose, T.K. 2003. In advances in biotechnology Engineering/Biotechnology (Ed:T.Scheper), vol.85, Springer, New York. DOI 10.1007/3-540-36466-8

Goh, C.S., Tan, K.T., Lee, K.T., Bhatia, S. 2010. Bio-ethanol from lignocellulose: status, perspectives and challenges in Malaysia, Bioresource Technol., 101 (13), 4834-4841.

Hanim, S. S., Noor, M.A.M., Rosma, A., 2010. Effect of autohydrolysis and enzymatic treatment on oil palm (Elaeis guineensis Jacq.) frond fibres for xylose and xylooligosaccharides production, Bioresource Technol., Article in Press, doi:10.1016/j.biortech.2010.08.017

Kumar, S., Singh, S.P., Mishra, I.M., Adhikari, D.K. 2009. Review. Recent Advances in Production of Bioethanol from Lignocellulosic Biomass. Chem. Eng. Technol. 32, No.4, 517-526.

Lynd, L.R., Weimer, P.J., van Zyl, W.H., Petrorius, I.S., 2002. Microbial cellulose utilization: Fundamental and Biotechnology. Microbiol. Mol. Biol. Rev. 66, 506-577

Moilanen, U., Kellock, M., Galkin, S., Viikari, L. 2011. The laccase-catalyzed modification of lignin for enzymatic hydrolysis. Enzyme Microb. Technol., 49(6-7), 492-498

Pandey, A. Soccol, C.R. Nigam, P. and Soccol, V.T. 2000. Biotechnological potential of agro-industrial residues: Sugarcane bagasse. Bioresource Technol.74, 69-80
Perez, J., Minoz-Dorado, J., Rubia, T., Martinez, J., 2002. Biodegradation and biological treatments of cellulose, hemicellulose and lignin. Int'l Microbiol. (5), 51-63

Sheil, D., Casson, A., Meijaard, E., Van Noordwijk, M., Gaskell, J., Groves, J.S., Wertz, K., Kanninem, M., 2009. The impacts and opportunities of oil palm in Southeast Asia, CIFOR, Bogor, Indonesia. p. 6

Sun, Y., Cheng, J. 2004. Hydrolysis of Lignocellulosic Materials for Ehanol Production: A Review. Bioresource. Technol., 83, 1-11

Wyman, C.E., Spindler, D.D., Grohmann, K. 1992. Simultaneous Saccharification and Fermentation of Several Lignocellulosic Feedstocks to Fuel Ethanol. Biomass and Bioenergy, Vol.3 (5), 301-307

Yu, Z., Jameel, H., Chang, H. M., Park, S. 2012. A Study in Lignin Inhibition for Enzymatic Hydrolysis of Woody Biomass. Proceedings of 12AIChE Annual Meeting, February11, 2012, Pittsburgh,PA, USA. www.aiche.org/Proceedings/Abstract. aspx?paperID=270943 (diakses tanggal 1 Oktober 2013)

Yunus, R., Salleh, S.F., Abdullah, N. and Biak, D.R.A. 2010. Effect of ultrasonic pretreatment on low temperature acid hydrolysis of oil palm empty fruit bunch, Bioresource Technol., 101(24), 9792-9796

http://ditjenbun.pertanian.go.id/statis-36produksi.html. Perkembangan Produksi Komoditi Perkebunan 2008-2013. (diakses tanggal 30 Mei 2014)

www.novozymes.com. Application Sheet Cellic ${ }^{\circledR}$ CTec2 and HTec2 -Enzymes for hydrolysis of lignocellulosic materials. (diakses tanggal 17 Mei 2013)

http://www.nrel.gov/biomass/analytical prosedures. National Renewable Laboratory. 2010. Analitical Prosedures of Standard Biomass Analysis. Available electronically (diakses tanggal 12 Juli 2013) 